\title{
V(D)J Recombination-Activating Protein 2
}

National Cancer Institute

\section{Source}

National Cancer Institute. V(D)J Recombination-Activating Protein 2. NCI Thesaurus. Code C80073.

$\mathrm{V}(\mathrm{D})$ J recombination-activating protein $2(527 \mathrm{aa}, \sim 59 \mathrm{kDa})$ is encoded by the human RAG2 gene. This protein plays a role in the mediation of $\mathrm{V}$-D-J recombination. 